\title{
Rethinking the Iranian Islamic Revolution of 1979 with the Security Dilemma of the Cold War
}

\author{
1979 İran İslam Devrimini ‘Soğuk Savaşın Güvenlik İkilemi’ ile \\ Yeniden Düşünmek
}

\author{
Meral BALCI ${ }^{*}$ \\ Esra DENIZZ*
}

\begin{abstract}
The case of Iranian Revolution can be interpreted in different ways in the light of the fact that it is still a revolution that continues to be written and discussed too much about. The study of the Iranian Revolution in literature, in general, confronts a growing resistance with the influence of the opposition people who oppose the oppression of the Pahlavi Dynasty dictatorship and grows under the influence of the Islamic phenomenon. However, in order to understand the Iranian Revolution, the perspective that is focused on the internal dynamics will not be sufficient. The external dynamics and the interaction of external dynamics with these actors must be a further perspective that needs to be focused to understand this particular revolution.

In this article, the differences of the Iranian Revolution are evaluated in a different perspective from the point of view of the literature. Rather than explaining the revolution with the historical process, it focused on the external dynamics that constitute the historical process. While evaluating the external dynamics, it is explained that the anarchy created by the Cold War in the international system through the security dilemma, and that the internal dynamic effect of this dilemma in a strategic country such as Iran could be realized by developing the anti-imperialist identity building of Khomeini through discourse and integrating all opposition groups. While evaluating the external dynamics, it is explained that the anarchy created by the Cold War in the international system through the security dilemma, and that the internal dynamic effect of this dilemma in a strategic country such as Iran could be realized by developing the Anti-Imperialist identity building of Khomeini through discourse and realizing the Islamic revolution of all opposition groups.
\end{abstract}

Keywords: Cold War, Iran, Islamic Revolution, Security,

* Doç. Dr., Marmara Üniversitesi, Siyasal Bilgiler Fakültesi, Uluslararası İlişkiler Bölümü, mbalci@marmara.edu.tr, Orcid: 0000-0003-3638-5339

* $\quad$ YL Öğrencisi, Marmara Üniversitesi, Sosyal Bilimler Enstitüsü, Uluslararası Politik Ekonomi Bölümü, denizesra35@gmail.com, Orcid:0000-0002-6266-3972 


\section{Öz}

İran Devrimi bugün bile üzerine çok fazla yazılan, tartışılan bir devrim olması itibari ile farklı açılardan yorumlanabilmektedir. İran devriminin literatüre giren incelemeleri genel anlamda Pehlevi Hanedanlığının diktatörlügünün baskısına karşı koyan muhalif halk ve İslam olgusunun etkisi ile büyüyen bir direniş olarak karşımıza çıkmaktadır. Ancak İran Devrimi’nin anlaşılması için sadece iç dinamiklere yoğunlaşılan bakış açısı yeterli olmayacaktır. Dış dinamikler ve dış dinamiklerin aktörler ile etkileşimi bu şahsına münhasır devrimi anlayabilmek için odaklanılması gereken ayrıca bir perspektif olmalıdır.

$\mathrm{Bu}$ makalede, İran Devriminin farklılığı literatürdeki bakış açılarından farklı bir perspektif ile değerlendirilmiştir. Devrimi tarihsel süreç ile açıklamadan ziyade tarihsel süreci oluşturan dış dinamiklere odaklanılmıştır. Dış dinamikleri değerlendirirken Soğuk Savaşın uluslararası sistemde yarattığı anarşi, Güvenlik İkilemi üzerinden açıklanmıştır. Mevcut iki kutbun yarattığı ikilem ise İran gibi stratejik bir ülkede, Humeyni'nin 'Anti-emperyalist' kimlik inşasını oluşturarak tüm muhalif grupları birleştirebilmesine ve böylece de İslam Devrimini gerçekleştirebilmesine olanak sağlamıştır.

Anahtar Kelimeler: Soğuk Savaş, İran, İslam Devrimi, Güvenlik

\section{Introduction}

Revolution is a social, political, cultural, and an economic phenomenon that opens the doors of a new and different era by closing down a period that has been experienced. They generally affect not only the country where the revolution is taking place, but also the surrounding countries and even the entire international system. As revolutions can influence the entire international system during and after them, they can also be affected by the existing parameters of the international system.

The most important external dynamic that should not be ignored in the process until the Iranian Revolution in 1979 was the insecure structure of the Cold War which has distrusted and isolated the international system. In this insecure environment, the existence of the countries that want to secure themselves in the bipolar system between the USA and the USSR by joining one of them, as well as those who deny these two poles, has brought the international system into a total anarchy during the Cold War years. The Pahlavi Dynasty's close relations with the United States and the United States' moderate attitude towards Iran to keep the USSR out of the Middle East were seen as the US colonialism for the Iranian people. Undoubtedly, the Iranian people's interpretation of the United States' approach to Iran as 'exploitation' could be justified. The fact that Iran's oil and natural gas is run by US and UK companies and that Reza Shah has imposed his income and political support on the Iranian people as dictatorship has led the Iranian people to seek a "liberating" leader. The US's support of the repressive policies implemented in Iran, which was one of the most important allies of the US in the Middle East during the cold war, in which the United States never wanted to lose, led the Iranian people to gather around Khomeini's "neither East nor West, only Islam" identity, which could bring together all opposition groups. The 'anti-imperialist' policy through the oppressive dilemma of Khomeini, which soon brought together all opposition groups in Iran, allowed Iran to make the Islamic Revolution which would deeply affect Iran and the whole world in 1979. One of the most fundamental differences of the 
Iranian Revolution was the unification of all dissident groups, with only a verbal partnership, without determining the regime to be brought after the revolution. This, of course, was possible by the fact that Humeini had analyzed the conjuncture very well, made the right moves as a result of this analysis and constructed a common identity.

The key question that this article wants to answer is how the "anti-imperialist" identity building which was created by Khomeini by evaluating the conjuncture as a result of the security dilemma experienced in the Cold War in the development of the 1979 Revolution in Iran, in particular in its external Dynamics nature, has turned into a social movement.

\section{Security Dilemma And The Cold War: Theoretical Framework}

The historical development of the concept of security in international relations has progressed in parallel with the wars in the world. Although first emerged in the 1940s with the name of Strategic Studies, it started to go out of the category of Strategic Studies since 1980 (Açıkmeşe, 2014, p. 241-242). From the 1980s onwards, researchers have started to produce theories on the security concept by looking at the it from different perspectives. Although the reflection of the concept of security on international relations was based on the Treaty of Westphalia in 1648, the focus of the researchers on this concept as a separate sub-discipline emerged after 1980 due to the necessity of explaining the changing war conditions. The beginning of the Cold War after the close combats in the First and Second World War revealed the necessity of a better understanding of the concept of "security" and removing it from certain patterns. The birth of the concept of security dilemma was also realized during the Cold War. In this section of the study, the concept of "Security Dilemma" will be explained and the Cold War period will be examined within the framework of the concept of "Security Dilemma".

\section{I.I. The Emergence of Security Dilemma}

"The race in armaments and the war itself are explained in the last resort, therefore, as the result of man's universal sin."

Herbert Butterfield ${ }^{1}$

In order to understand the international system, it is necessary to understand the nature of states, and to understand the nature of states, it is necessary to understand the nature of individuals. Herbert Butterfield, in his book History and Human Relations, published in 1951, focused on the conflict in human relations and tried to explain the cause of conflicts in the international system. Human conflicts are the basis of human dilemmas, which, according to Butterfield, the source of basic human dilemmas is a sense of competition that cannot be prevented and impossible to control

1 For detailed explanation, see: Herbert Butterfield, History and Human Relations, Collins St. James's Place, London, 1951, p. 22. 
(Butterfield, 1951, p. 20). The unpredictable sense of competition constitutes a mathematical formula of "human conflict" that Butterfield calls "tragedy" 2 . As Butterfield describes as "the real world of international relations", the thesis of "the absolute deadlock or the unstoppable dilemma lies within the geometry of human conflict" (Butterfield, 1951, p. 20) is the building block of the concept of security dilemma. Butterfield created the basic point of view of the concept of "security dilemma" by thinking through the individual, and the concept of human nature that he accepts bears the traces of Hobbes. Butterfield accepts Hobbes's approach to human nature and expresses that people are fighting because of "Counter-Fear". The term 'Counter-Fear' for Butterfield is a characteristic of "the situation in which absolute human impasse has become a conflict". The individual can literally feel the fear he or she experiences, but he or she can't get into the counterfear of others (Butterfield, 1951, p. 21) this makes it clear for Butterfield that the human impasse is a tragedy. At the same time, Butterfield interprets the absolute impasse or irreducible dilemma as a "situation in which decision makers who do not intend to fight in the idea have to fight in the action (Bilgiç, 2011, p. 124)". According to Butterfield, blaming decision-makers (decisionmakers on both sides) is no use because the real reason for the tragic humanitarian impasse (wars) caused by the armament race, i.e. competition, is Hobbessian Fear (Butterfield, 1951, p. 22).

In order to fully understand the "Counter-Fear" expression, which constitutes the point of view of the Butterfield's security dilemma, it is necessary to know that Butterfield has evaluated the "fear" approach through the "Hobbesian Fear" . Because Butterfield created the basis of the concept of security dilemma on the chain of "Hobbessian Fear-Sense of Competition-Human PredicamentCounter Fear-Conflict (Tragedy)". The basis of Hobbessian Fear is "the fear of death". In other words, "the end of human existence" is the most severe and primary fear of man (Blits, 1989, p. 417) and according to Hobbes, as a result of this fear, every human being, by nature, has the desire to live. Therefore, every person has the freedom to use his power to protect himself (Hobbes, 2011, p. 91). At the same time, Hobbes states that the muscles and similar parts that make up the human body resemble the form and power that forms the state (Hobbes, 2011, p. 158). The fact that Butterfield was influenced by Hobbes during the birth of the concept of security dilemma and that he gave a basic point of view to the concept of security through "fear" in order to understand the environment of insecurity is not difficult to understand when the etymological examination of the concept of "security" is made. As J. Frederik M. Arends points out in his work, the contemporary concept of "security" has been blended with three elements in the historical process and gained its present meaning. These are, "the objectives of the ancient Athenians to prevent their empire from collapsing, the religious emphasis of the Romans who used the concept of securitas, and the goal of the Hobbesian philosophy to prevent civil wars"4.

2 Herbert Butterfield accepts the Hobbesian approach of human nature and states that one cannot prevent the sense of "competition" inherent in human nature to survive, so one's predicament would inevitably turn into conflict, and he expresses this as a "tragedy" because he believes that conflicts will be absolute. For more information, see: Herbert Butterfield, ibid., pp. 20-22.

3 See: Jan H. Blits, Hobbesian Fear, Political Theory, Vol.17, No.3 August 1989, pp. 417-431.

4 For more information, see: J. Frederick M. Arends, Homeros Hobbes and Beyond: Dimensions of The Concept of 
When the word Securitas is examined in depth with their Latin origin, it is seen that it means "lack of concern". As Arends notes, the word can be explained by a number of words that are semantically related to "fear", "fear of death" and the sense of "trust" that accomplishes these meanings. (Frederik and Arends, 2009, p. 5). Hobbes' concept of "security" is based on the Greek historian Thucydides. Thucydides shows the civil wars as the cause of the destruction of the Athenian Empire and contributes to the understanding of security with a different perspective as "the decline, the prevention of defeat" (Frederik and Arends, 2009, p. 7). Thus, Hobbes' approach to the concept of security developed within the framework of "state and absolute sovereignty". According to Hobbes, "Sovereignty is the absolute representative of the state (Hobbes, 2011, p. 158)." In the case of the survival of the states, which is adapted to the states based on the Hobbes' concept of human nature, states, such as individuals, are trying to maintain their existence/ sovereignty in the anarchic structure of the international system with the motivation of "fear". The argument that constitutes the basis of the concept of Security Dilemma is that the counter fear situation among individuals has turned into a state of mutual distrust in the international system. During the Cold War, the concept of security dilemma was shaped by the concept of Anarchy, with Herz defining the social structure. John H. Herz, who shaped the concept of Security Dilemma with the structure of the international system, defines the international system as a basic social constellation in which people live side by side with each other in different groups and that there is a dilemma when different groups cannot provide unity. According to Herz, humanity has always had to face a dilemma throughout history. ${ }^{5}$ Because Herz states that people in different groups form the political structure. From this argument, Herz describes the society as a society in anarchy, and thus the international system as an anarchic system. The argument that Herz expresses is that there is also the Security Dilemma in every situation where anarchy is present (Herz, 1950, p. 157). It should be noted that the logic of the Security Dilemma is based on understanding the nature of the international system rather than explaining a particular event.

Herz adescribes the nature of the international system in 1950 through the security dilemma. According to Herz, groups within the "constellation" defined by the international system are concerned about "exclusion, aggression and domination of the other groups." This concern is the fear of survival fed by Hobbesian Fear. The group or individuals of concern need to be empowered to maintain their existence, which is perceived as "distrust" by other groups. Since Herz defines these groups as "competitive unions" in the international system, no group will feel completely safe in this world of competitive unions. Therefore, the "security" situation arising from "insecurity" will reveal the "power competition", which will lead to the emergence of a "security dilemma" by entering a vicious cycle of "power competition". Herz describes the Cold War between the United States (USA) and the Soviet Socialist Republics union (USSR) in those years as, "The heartbreaking plight in which a bipolarized and atom bomb-blessed world finds itself today (Herz, 1950, p.3)”.

"Security" in European Tradition, Journal of International Relations, Vol.6, No. 22, Summer, 2009, p. 4.

5 Like Butterfield, Herz has tried to explain the individual's inherent fear through Hobbesian Fear with the expression "kill or to be killed", but the obvious difference between them is that Herz carried the conflict from the dilemma to the "groups". For more information, see: John Herz, Political Realism and Political Idealism: A Study in Theories and Realities, Chicago University Press, 1951, p. 3. 
As a liberal outlook, Jervis states that the anarchic nature of the international system determines and encourages the behavior of states ${ }^{6}$ by not interpreting the Security Dilemma very differently from the realist perspective. In addition, Jervis interpreted the security dilemma as follows: "Even though states are sure of their mutual intentions at that moment, they want to protect themselves with their 'desire to exist' in the future in case this situation changes. Therefore, alliances and armaments created to protect themselves will be perceived as 'hostile' by other states". According to Jervis, "Because each state can protect itself, it is likely to gain the ability to threaten others (Jervis, 2001, p. 36). With this view, Jervis summarizes the approaches of realists and liberals to the security dilemma. According to Jervis, if the Cold War had a security dilemma, both sides would be busy defending themselves. Even if mutual friendly compromises were made, States would have to fall into the position of "insecurity" (Jervis, 2001, p. 37). But the fact that the Cold War does not end with military conflict and that concessions have a "softening" effect in the Cold War, rather than insecurity, is a clear indication that Jervis, Herz and other realist and Liberal security dilemma theorists are trying to explain this concept with only materialist approach, and therefore the concept is neutered and left incomplete.

\section{I.2. Rethinking the Security Dilemma with Identity}

"Desire aims to fit the world to the mind, belief aims to fit the mind to the world."

Alexander Wendt ${ }^{7}$

It seems that the realist and liberal perspective has failed to explain the security dilemma created by the Cold War, and the main reason for this lack is that the realists and liberals do not take into account the social interaction and identity perceptions. In this article, the theoretical framework of the security dilemma will be based on the constructivist perspective and the interpretation of the concept through 'identity'. The re-interpretation of the security dilemma on the phenomenon of identity can be interpreted as a result of the late acceptance of Constructivism as a social theory among the theories of international relations. JJ Suh, who believes that the security dilemma needs to be rethought after the Cold War and who makes the first identity-based contribution to the concept of security dilemma, expresses that the security dilemma emerging from the competition between the US and the USSR in the Cold War is not sufficient to create "hostility" (Suh, 2006, p.5). Sufficient conditions to intensify hostilities and create a security dilemma can be achieved through the construction of "counter-identity". Suh states that the construction of 'counter-identity' can be caused by social interaction, and this social interaction will develop in the 'uncertainty of intention' anarchy brought by the armament race (Suh, 2006, p.5). Suh explains the process of the emergence of the security dilemma with the Antagonistic Identity

6 Robert Jervis interprets the phenomenon of "anarchy" that the realist theoreticians of the Security Dilemma focus on as "encouraging behavior that exacerbates all concerns". For more information, see: Robert Jervis, Cooperation Under The Security Dilemma, World Politics, Cambridge University Press, February 1978, p.167

7 See: Alexander Wendt, Uluslararası Siyasetin Sosyal Teorisi, Küre Yayınları, İstanbul, 2012, p.155. 
Construction model ${ }^{8}$ that the states have constructed their identities as contradictory and noncontradictory in the case of uncertainty about the intentions of others. When the Cold War is evaluated with Suh's 'counter-identity' construction, we can say that the US and the USSR have constructed 'ideological identity' through ideological concern, which means that the 'ideological identity' construction has brought the international system to security dilemma. The social interaction process, which underlies the ideological identity building, has been limited in explaining the international system because of the dominance of realism during the Cold War era. Herz, for example, came to the states from individuals, and to international system from states, and thus explained that the elements of the security dilemma are social facts. Herz stated that the "homo homini lupus" situation, which the security dilemma benefited from, does not mean that social collaboration is not a fundamental reality of social life, and that even the phenomena of 'cooperation' and 'solidarity' tend to be elements of conflict (Herz, 1950, p.157-158) and again entered into the Realist paradigm.

Apart from the fact that the states which are in cooperation and solidarity can come into conflict, the driving force that can cause this conflict is the conflict of interests. As Wendt states, "identities are the basis of interests" and states will redefine their interests in the process of defining events (Wendt, 2013, p. 8-10), the process in which these conflicts of interest or what Herz refers to as "political conflicts" turn into a security dilemma is the construction of "wantonness" created by states against each other. The construction of wantonness is the process of building mutual identity, which stems from the above-mentioned anxiety situation, where states try to build trust with insecurity and hence the trust they build is perceived as insecurity. It is possible to say that the construction of confidence-insecurity situation was also built as a "social threat" in the Cold War. The fact that the United States defines communism as a threat, but the USSR regards capitalism as a threat to the international system is the "social threat" that the two states have built. "Contentious power policies" associated with the concept of the Wendt's security dilemma are, in the words of Wendt, the power competition entered in the existing order problem (Wendt, 2013, p. 12-14). The beginning of states' power competition is the final moment when mutual identity perceptions become "hostile". Although it is an undeniable fact that the power competition between the US and the USSR in the Cold War has separated the international system into two poles with its 'ideological' based identity, the most fundamental factor underlying the existence of the non-aligned states that form the third pole is that they do not want to separate because of this ideological identity. It is known that not only non-aligned states, but other states which have to be involved in a pole with fear of existence, are forced to deal with the problems of sovereignty and stability due to the ideological separation of the Cold War. In the second part

8 According to Suh, the security dilemma is inevitable if the states choose to construct a mutual 'antagonistic' identity. However, it is possible to exit the security dilemma without conflict. Suh explained this situation by exemplifying the Cold War. In this model, Suh created the emergence of the security dilemma in a systematic way that resembles a mathematical formula in the form of "top to bottom". See: J.J. Suh, ibid., pp. 5-8

9 The English translation of this phrase, which is attributed to Hobbes, is "A man is a wolf to another man". In the literature, it is claimed that the term was first used by Roman poet and playwright Titus Macchius Plautus. See: Hümeyra Karagözoğlu, "Homo Homini Lupus": Thomas Hobbes’un Ahlâk Felsefesi Üzerine, M.Ü. İlâhiyat Fakültesi Dergisi, 2006, p. 215. 
of this article, this situation will be examined in detail while explaining the process that led Iran to the revolution. Lindley, another theorist who explained the security dilemma with 'identity', explained the security dilemma on the island of Cyprus, while the expressions in the literature "need to be reviewed again" (Lindley, 2007, p. 225) says that these conflicts can be avoided with the construction of common identities. If we examine Lindley's "common identity" through the Cold War, we can say that "the reason why the United States won the Cold War without entering into a military conflict with the USSR is because it has formed a common identity based on liberal individualism" (Ralph, 1999, p. 721). Therefore, the identity built with the social interaction that Herz cannot see and the realists ignore is a key phenomenon that can create a security dilemma and also overcome this security dilemma without the need for military confrontation.

The Cold War was a discriminatory process in which the security dilemma was built on the international system through ideological identity. The US and the USSR have built themselves with ideological foundations, causing them to race to create a "safe area" through their ideological identity. They wanted to include other states in the international arena to their 'safe areas', in other words, in the Western or Eastern bloc, and the atmosphere of anarchy they have created in the international system has left permanent traces of their influence since the Cold War era in many states, such as Iran, which will be examined in this article.

\section{A Different View Of Iranian Islamic Revolution}

"The interconnected tapestry of domestic histories and international history is one of the most salient features of the Cold War era."

David S. Painter, Melvyn P. Leffler ${ }^{10}$

The security dilemma anarchy resulting from the separation of ideological identity created by the Cold War affected most the Third World countries, the anarchy experienced outside carried into these countries, and the conflict arising from the anarchy resulted in revolution in most of them. In the countries mentioned, revolutions were either defined by ideological identities or emerged as the result of the independence wars that they carried out in order to escape the oppression of hegemon power by being influenced by those who rejected the rule of being part of a pole during the Cold War years. However, the Iranian Revolution was quite different from the revolutions that took place in countries such as China, Vietnam, Cuba and Algeria in those years. The most important reason for this difference is, of course, the Islamic emphasis ${ }^{11}$ on "neither East nor West" stability and security built by Khomeini. The fact that Khomeini comes to the face of the Iranian people, who are disturbed by the ideological polarization of the USA and the USSR and the pressures imposed on their countries because of this polarization, with the words

10 See: David S. Painter And Melvyn P. Leffler, Origins of the Cold War: An International History, Second Edition, UK by Routledge, 2005, p. 2.

11 Khomeini's statement clearly emerged from 1980, that is, after the revolution, as a foreign policy discourse. For more information, see: https://www.apnews.com/84d3401e09d6e88dac38c9cbe6f81ffb (Date of Access: 17.10.2018.) 
"neither East nor West", has created the belief in the Iranian people that they have found their liberating leader. With this argument, it can be understood how Khomeini can bring together different opposition groups. In this section of the article, rather than analyzing the domestic dynamic effects' that are effective in the formation of the Iranian Islamic Revolution, which is always encountered in the literature, the security dilemma that emerged with the "ideological identity separation" built by the USA and the USSR during the Cold War period will be explained as "contribution to the internal dynamics of the Iranian Islamic Revolution".

\section{I. Towards The Iranian Revolution}

After the Second World War, two superpowers emerged that could fill the gap of power in the international arena. It was inevitable that these two superpowers were the United States and the USSR, because the wrecks of Britain and France, which played an important role in the international power balance in the First and Second World Wars, required many years to recover. The defeat of Germany, Italy and Japan in the Second World War left two important actors in the balance of international power (Sönmezoğlu, 2009, p. 29-38). In the last years of the war, the ideological influence of the USSR, which it tried to implement in the Middle East and Asian countries, did not escape the attention of the United States as well as its efforts to lead communist regimes in Eastern European countries under the pretext of preventing Germany's occupation. The security dilemma of the Cold War, which divided the international system into two poles and handed over to 'anarchy', started over the 'reading of intention' as described in the theoretical part. ${ }^{12}$

The event that started the security dilemma in the Cold War with "reading intent" was a crisis in Iran between the years of 1945-46. During the Second World War, the United States, Britain and the USSR, which entered the territory of Iran under the agreement ${ }^{13}$, agreed to pass aid to the Soviets against Germany through Iran, would leave the territory of Iran on March 2, 1946 at the latest. Although the United States and Britain withdraw their troops from Iran after the war ended, the Soviets did not intend to leave the opportunity easily (Abdulrahman, Ghazali, Fauzi, NAorazhan and Yaacob, 1946, P. 1546). The possibility to control Iran and extend Russian sovereignty to the Persian Gulf seemed to be a historic opportunity for the Russians. Iran was

12 According to Ken Booth and Nicholas J. Wheeler, "The security dilemma is a two-level strategic predicament in relations between states and other actors, with each level consisting of two related dilemmas (or propositions that can be assumed to be valid) which force decision-makers to choose between them. The first and basic level consists of a dilemma of interpretation about the motives, intentions and capabilities of others; the second and derivative level consists of a dilemma of response about the most rational way of responding." See: Ken Booth, Nicholas J. Wheeler, Rethinking the Security Dilemma, Researchgate, February, 2008, p. 2-3. https://www.researchgate.net/ publication/37146990_Rethinking_the_Security_Dilemma (Date of Access: 19.10.2018.)

13 The first article of the Treaty of alliance between the United Kingdom, the Soviet Union and Iran on 29 January 1942 stipulates that all states which are parties to the Treaty shall respect "territorial integrity, sovereignty and political independence of Iran". The impulse that led the United States to read intention is that the military structure of the Soviets remains within the borders of Iran, despite the end of the agreement. According to the US, the Soviets did not comply with the provisions of the treaty, including the first article. See: RALPH A. COSSA, Iran, The Institute For National Strategic Studies, July, 1990, p. 6. 
able to extract the Soviets from their territory only by giving them 51\% of North Iranian oil (Cossa, 1990, p. 8). On April 4, 1946, when the secret agreement was not ratified in the Iranian parliament, Russian pressure was inevitable for the Iranians, on the other hand, when the secrecy of the agreement was eliminated, the Iranians reacted strongly to the government. When the Soviet pressure on Iran increased, the United States did not leave its important ally in the Middle East alone, and on September 20, 1947, it positioned ${ }^{14}$ itself alongside Iran and against the Soviets. The "wantonness" built by the Soviets from the perspective of the United States has also laid the foundations of the Cold War. The first traces of anarchy created by the "power race" entered by the two hegemon states in the international system were felt in the Middle East.

The construction of the separatist ideological identity of the Cold War accelerated by the 1950s through the security dilemma created by the United States and the USSR. The security dilemma that escalated rapidly between the two countries brought the competition for arms with it. The arms race at the heart of the competition also revealed the need for oil and attracted the attention of both countries to the Middle East. The United States had to keep the USSR away from the region in order to maintain its dominance over oil resources in the Middle East, and therefore Iran was vital both to its resources and geopolitical position. While the security dilemma created by the Cold War reached its peak in these years, there has been an important development in Iran. Mossadegh, the leader of the National Front against the British company ${ }^{15}$ that runs Iranian oil, has also taken the support of religious leaders and raised the agenda for the nationalization of oil. On 19 February 1951, when the law on full-nationalization of oil was rejected by the Shah's Prime Minister General Ali Razmara, the Iranian people began to accuse Shah of being a puppet of England and the United States by opposing the Shah's rule. After the assassination of Razmara on the days of the street protests and riots, the nationalization of oil law adopted by the Shah on March 15th to calm the people concerned the United States, which sought to rule against the USSR in the region (Mostafazadeh, 2017, p. 85). The growing popularity of Mossadegh in Iran, which gained victory in the elections thanks to his support for nationalization and liberalization, was an unexpected development for the Shah. Realizing that he underestimated Mossadegh, the Shah needed Western allies to regain his power, and the United States could not leave Iran alone with the threat of communism. Butterfield's argument that the competition that constituted the security dilemma would surely result in tragedy took place in Iran in 1953 with Operation Ajax. (Uygur, 2016, Access: https://iramcenter.org/1953-darbesi-ve-hatirlattiklari/\#.W3dRZtG5Sls. whatsapp) The brave and hasty steps taken by the United States against the threat of the USSR have caused the Iranian people to internalize the idea of "oppressor-oppressed" that led Iran to the 1979 revolution. The idea that the USA and Britain are behind the coup against Mossadegh

14 The United States has pledged to protect Iran's territorial integrity against the dangers posed by the USSR by cancelling Iran's oil deal. See: Fahir Armaoğlu, 20. Yüzyıl Siyasi Tarihi, Alkım Yayınevi, 2009, p. 518.

15 The said company, Anglo-Persian Oil Company (APOC) is a British company founded in 1908 after the discovery of a large oil field in the city of Masjed Solemanan, Iran. It's the first company to extract oil from Iran. In 1935 (APOC), Anglo-Iranian Oil Company was renamed. It became British Petroleum Company (BP) in 1954. For the resourse, see: Edward Henniker-Major, Nationalisation: The Anglo-Iranian Oil Company, 1951 Britain vs. Iran, Seven Pillars Institute, V. 2., No.2, Summer, 2013, p. 16. 
has sharpened the opposition discourse against the Shah by increasing the hatred of the Iranian people for the great powers, especially the USA. The overthrow of Mossadegh in Iran provided a great convenience for Khomeini to realize the Islamic Revolution. In fact, the hatred of the Iranian people against the US and the interventionist powers has begun to bring together different opposition groups in the country.

In the years when the Cold War divided the international system, the two hegemon States, which entered the security dilemma outside, carried the anarchy they live outside in strategically important areas, as they did in the arms race against each other, by armed the local governments and the insurgents. Although the United States and the USSR never experienced a "tragedy" in the security dilemma during the Cold War, they have caused conflicts, namely tragedies, by distorting the states in the international system, which they split with ideological identity, through the idea of "me and the other". Nixon's statement ${ }^{16}$ in Guam on July 25, 1969 supports the aforementioned argument. ${ }^{17}$ The content of the announcement, called the Nixon Doctrine, meant that the United States could continue its dominance indirectly by providing training and defense services to soldiers or insurgents in the region, instead of directly sending their troops to the conflict in countries where the United States wanted to dominate against the USSR (İzzetti, 2006, p.76-77). The wars of Korea and Vietnam in Asia, which are of strategic importance for the two hegemon countries after the Middle East, has led to a great backlash in the US public opinion. The fact that American soldiers were dying in places where there was no American soil, and that in the same years the states that described themselves as unconnected to the interventionist hegemon states started to make the emphasis of independence stronger, triggered Nixon (Nguyen, 2014, p.15). The ideological influence that the United States was trying to create was jeopardized by the fact that the United States intervened directly to the states. Wanting to comply with the discourse of liberal individualism, the independent and free international world, Nixon tried to arm the US's allies and tried to renew the liberal image of the United States.

Iran was, of course, the most appropriate country in the Middle East, where the United States could withdraw the threat of communism from the region by providing arms support. Iran had to be equipped with good equipment in order to become a gendarmerie in the Gulf. The impact of US arms sales to Iran of 86 million dollars in 1969, 184 million dollars in 1971, and 500 million dollars on Iranian internal dynamics is that the rise of hatred in the Iranian people against the Shah and the United States in parallel with arms sales and the strengthening of the SAVAK ${ }^{18}$. The friendship and cooperation agreement between the Soviets and Iraq in 1972 accelerated the US armament of Iran and increased arms sales to \$ 2.5 billion in 1973 (Shawcross, 1991, p.194-209). In addition, the US sent thousands of US military personnel to Iran to train the Iranian army

16 See: İzzetullah İzzeti, (Trans. Hakkı Uygur) İran ve Bölge Jeopolitiği, Küre Yayınları, İstanbul, 2006, pp. 75-76.

17 For the analysis of polarization in Asian countries with Nikson doctrine, see: https://www.nytimes.com/1970/06/29/ archives/the-guam-doctrine-asian-nations-voice-anxiety.html (Date of Access: 19.10.2018.)

18 SAVAK was the secret police, domestic security and intelligence service of the Pahlavi dynasty. It was founded in 1957 to suppress opposition voices against the Shah with the help of the United States. Instead of the army, SAVAK was tasked to suppress the street protests. See: Serpil Üşür, Din Siyaset ve Kadın, Alan Yayıncılık, İstanbul, January, 1991, pp. 122-123. 
directly, instead of just selling weapons and maintaining Iran'S dominance (Izzetti, 2006, p. 81). All these developments made the Pahlavi monarchy a dictatorship in Iran and the Iranian people turned into an oppressed mass.

In 1977, opposition demonstrations began to increase in Iran, but Savak's attitude towards the opposition has become equally brutal. The harsh methods that SAVAK applied to the opponents had an adverse effect, and by 1978, the demonstrations had begun to clearly show that they were heading towards the revolution. The charismatic leader needed by the revolution was Khomeini, who at the time accused the Shah of being a puppet of imperialism, who also frequently expressed the emphasis of anti-imperialism (Halhalli, 2014, p.77). The basis for Khomeini to become a symbol of the revolution and to unite the entire opposition masses with the 'Islamic ideology' was the separation of the 'opressor' and the 'oppressed'19. Khomeini and the supporters of Khomeini described the imperialist great powers in Iran as "oppressor" in the separation of capitalism communism by the two powers that divided the international system in the security dilemma of the Cold War, and the countries that became the targets of imperial powers like the Iranian people as "oppressed" 20 . The Islamic ideological reading of this dilemma underlying its unifying role was the integration of religion, politics and society. The fact that the modernisation policies of the Pahlavi monarchy are advancing under the auspices of the United States ${ }^{21}$ and that the economic inequality between the people has gradually deepened have led to the formation of an identity crisis in the Iranian people (Üşür, 1991, p.24). Since the crises are also the beginning of solutions, Khomeini has transformed the identity crisis of the Iranian people and has managed to obtain all the opposition support that will bring the Islamic Revolution by building a "common identity" through Islam.

In order to summarize the impact of the security dilemma created by the Cold War on Iran's internal dynamics, the chain mentioned above in the form of "Hobbessian Fear-Sense of Competition-Human Predicament-Counter Fear-Conflict (Tragedy)" has been realized in the first stage with its players in the international system as follows;

Hobbessian Fear: After the Second World War, the USSR did not want to leave the strategic regions it entered due to German occupation, and the United States was concerned about the idea of losing control of the international system to the USSR. The fear of the survival of the two great

19 "The two Pahlavi leaders ruled the country without the consent of the community by extorting power." In this statement, it is clearly seen that he drew attention to the dictatorship of the Shah. Baqer Moin, Son Devrimci Ayetullah Humeyni, Elips Kitabevi, January, 2005, p. 195.

20 In Islamist ideology, the oppressors were the ones who plundered the material and spiritual values of the country in accordance with the wishes of the West and the oppressors were the ones who were oppressed by the Shah. In this opinion, as Imam Hussain's martyrdom at Karbala, although it was the most important factor not to bow down to the submission, it was necessary to seek the justice of the leader who would save them from the Shah's cruelty without question. Serpil Üşür, ibid., p.100-101.

21 Due to the increase in oil revenues, migrations from rural areas to urban areas have led to a precipice in city building. On the one hand, while the capitalist economy and the lifestyle began to settle, on the other hand, there were poor people who came from rural areas and stayed in slum areas of the city, and felt the economic inequality deeply. It was not hard for the clergy to pull this segment with them through the 'oppressed' identity. Hamid Ahmedi, (trans. Hakkı Uygur) İran Ulusal Kimlik İnşası, Küre Yayınları, January 2009, p. 154. 
powers in the international system has progressed in parallel with the areas in which they could expand their dominance in these years.

Sense of Competition: The desire of the two hegemon states to adopt their ideological influence to the international system has caused them to enter an arms race in order to create mutual fear and defend themselves. The two hegemon States, which began to export weapons and ideology in order to expand their sphere of domination, thus expanded the area of the security dilemma they entered. The gendarmerie mission to Iran in the Middle East has provided the Shah leadership with sufficient equipment and confidence for dictatorship, as a result of the U.S. acting with a sense of competition.

Human Predicament: The fact that the US and the USSR included other countries in the arms race led the Iranian Shah, who wanted to maintain his power, to authoritarianism, and in the context of the ideology that the United States has exported, sought to implement Western-style modernisation in the country without planning. The fact that the Shah is resisting the Iranian people, who are disturbed by the foreign powers' involvement in their country's administration and culture, with the arms and military structure that the United States has provided (SAVAK) has raised the tension of the conflict between the Iranian people and the Shah. The idea that the Iranians have lost their identity and independence has turned into fear of extinction, which has caused a stage of conflict and is the basis of the human predicament.

Counter Fear: The fact that both the Soviets and the United States wanted to expand their sphere of domination by entering the race to export their ideological identities has brought to them the belief that they will "lose" the moment they abandoned this motivation. For this reason, they have accelerated the security dilemma they have entered in order to protect themselves from any possible attack from the other side. This acceleration was reflected in Iran over the regional competition. For the United States, the stability of Iran, which is the most important country in the Middle East to prevent the export of communism, was very important. Therefore, the Shah's authoritarian attitude could be ignored for the United States. The ignored Iranian people and the growing anarchy in the country have led to the tragedy that would result in Iran's revolution.

Conflict (Tragedy): Although the USA and the USSR did not engage in one-on-one conflict in the security dilemma they entered, the anarchy they created in the areas of domination led the conflict to revolution in Iran. The Iranian people, who refused to be isolated by ideological identity, began to come together despite having different ideologies and belonging to different groups in order to rid themselves of the authoritarianism of the Shah and the oppression of the SAVAK. As a matter of fact, the reason they came together was the "partnership" created by ideological separation. The anarchy of the security dilemma has transformed the predicament into tragedy, creating a new 'opressor-oppressed' dilemma in Iran. The dilemma created by modernization and westernism could only be overcome by a unifying common identity. As Khomeini's strategy of "neither East nor West, only the Islamic Republic" has proven, both sides of the dilemma have been rejected, and the belief in Iran that the evil order is the corruption caused by ideological 
expulsion has been accepted by the Iranian people. The anarchy of the security dilemma created in the international system was defined through ideological identity, and was also overcome by the liberal identity being made into a common identity by the United States. The anarchy created by the security dilemma in Iran's internal dynamics was defined by a new dilemma in which the ideological oppression turned into a tragedy, and this tragedy was overcome by the construction of Khomeini’s "Common Islamic Identity".

\section{Conclusion}

Revolutions are national and international actions that leave behind a trace when they are finished, in which individuals are driven by mass psychology ${ }^{22}$ from the outside, and in which a charismatic leader is definitely needed in the movement initiated. In this study, the point that is wanted to be reached by looking at the Iranian revolution from a different angle is that the situation of the individuals being poked from the outside can be explained with international conjuncture.

The Cold War and its security dilemma brought the international system to polarization with ideological identity through the USA and the USSR, reducing the anarchy outside to countries and even to individuals. Hobbesian Fear is explained as the desire to sustain life in individuals, while for states it can be explained as the desire to not lose power and domination. Hobbesian Fear has been effective since the start of the security dilemma, but the situation in which states feel threatened by living spaces is the moment when they 'read intent'. The security dilemma is inevitable when the two states that are involved in the armament race are subconsciously "defending themselves" but one side is considered to be "malevolent" for the other side. The United States and the USSR, acting with the urge to protect the areas of domination in the Cold War where the construction of mutual wantonness gained speed, literally led the international system into anarchy. The reflection of the said anarchy to states of strategic importance, such as Iran, has been much greater. The feeling of the political and military power gained by the Pahlavi Dynasty with the support of the USA is that the foreign powers are under the control of the Iranian people and the loss of self is experienced. The main reason for the loss of self expressed as an identity crisis in the study was the fact that the West imposed its ideological identity on Iran. Iran's economic and political life, which suddenly returned into capitalism with its oil revenues, has led to an income gap in Iran. This situation caused the poor to fall into the dilemma of "opressor-oppressed". The leader of the Iranian people, who needed a charismatic leader for the revolution, was someone who could restore the lost values of Iran and remove the dominance of foreign powers over Iran. Although it is known that Khomeini is a strong opposition to the Shah,

22 The basic characteristic of mass psychology is that it does not matter how different or identical the individuals 'lives, jobs, characters and intelligence of the masses are, that is, all the characteristics that make individuals' individual'. Because these different or identical individuals gain a collective spirit as a result of massing and act collectively. For example, just as cells in an organism create an organism by coming together, mass formation is that individuals come together and acquire a common soul, a temporary entity with thought. Sigmund Freud, trans. Kamuran Şipal, Kitle Psikolojisi, Say Yayınları, İstanbul, 2015, p. 28. 
the anti-imperialist emphasis he developed in his speech and definition of the Shah as a Western puppet has allowed him to unite different opposition groups in Iran. The most important impulse of mass psychology in Iran was the 'anti-imperialist' roof. Although this is a separation between the US and the USSR in the security dilemma, Khomeini built the house to be built under that umbrella in Iran by building a common identity through Islam. The Mass, who wanted to end the persecution of the Shah regime, came together without distinguishing differences or similarities, and went after a leader with the common spirit and brought the Islamic Republic instead of constitutionalism. The security dilemma faced by the two hegemon forces in the international system was one of the main issues affecting the revolutionary process in Iran, the strategic country in the Middle East. The security dilemma outside, the Iranian people who led the oppressoroppressive dilemma and Khomeini, the liberating leader, have allowed a new order to be built.

\section{Bibliography}

Ahmedi, H. (2009) İran Ulusal Kimlik İnşası (Trans. Hakkı Uygur), İstanbul: Küre Yayınları.

Akgül Açıkmeşe, S. (2014) Güvenlik, Güvenlik Çalışmaları ve Güvenlikleștirme (Ed. Evren Balta) Küresel Siyasete Giriş, İstanbul: İletişim Yayınları.

Arends, J. F. ve M. (2009). Homeros'dan Hobbes ve Ötesine: "Güvenlik" Kavramının Avrupa Geleneğindeki Boyutları, Uluslararası İlişkiler Dergisi, Volume 6, Issue 22, p.3-33.

Armaoğlu, F. (2009) 20. Yüzyıl Siyasi Tarihi, Ankara: Alkım Yayınevi.

Bilgiç, A. (2011). Güvenlik İkilemini Yeniden Düşünmek Güvenlik

Çalışmalarında Yeni Bir Perspektif, Uluslararası İlişkiler Dergisi, Volume 8, Issue 29, p. 123-142.

Blits, J. H. (1989) Hobbesian Fear, Political Theory, Vol.17, No.3, s.417-431.

Booth, K. Ve Wheeler, N. J. (2008) Rethinking The Security Dilemma, Researchgate.

Butterfield, H. (1951) History and Human Relations, Collins St. James's Place.

Cossa, R. A. (1990) Iran: Soviet Interests, Us Concerns, Mc Nair Papers Number

Eleven, The Institute for National Strategic Studies. Sigmund, F. (2015) Kitle Psikolojisi, İstanbul: Say Yayınları.

Halhalli, B. (2014). Humeyni Dönemi İran Dış Politikası, Birey ve Toplum, Volume 4, Issue 8, p.75-96.

Henniker-Major, E. (2013). Nationalisation: the Anglo-Iranian Oil Company, 1951 Britain vs. Iran, Seven Pillars Institute, Volume 2, Issue 2, p.16-34.

Herz, J. (1951). Political Realism and Political Idealism: A Study İn Theories And Realities, Chicago University Press.

Herz, J. H. (1950) Idealist Internationalism and the Security Dilemma, World Politics, Vol.2 No.2, p.157-180. Hobbes, T. (2011) The Leviathan, Ankara: Pasific Yayıncillk.

İzzeti, İ. (2006) İran ve Bölge Jeopolitiği (Trans. Hakkı Uygur), İstanbul: Küre Yayınları.

Jervis, R. (1978). Cooperation Under the Security Dilemma, World Politics, Vol. 30, No. 2, Cambridge University Press, p. 167-214.

Jervis, R. (2001). Was the Cold War a Security Dilemma?, Journal of Cold War Studies, Vol. 3, No. 1 President And Fellows of Harvard College and the Massachusetts Institute of Technology, p. 36-60.

Karagözoğlu, H. (2006). "Homo Homini Lupus": Thomas Hobbes’un Ahlâk Felsefesi Üzerine, M.Ü. İlâhiyat Fakültesi Dergisi, s. 215-242. 
Lindley, D. (2007). Historical, Tactical, and Strategic Lessons from the Partition of Cyprus, International Studies Perspectives, Blackwell Publishing, Oxford, UK, p. 224-241.

Mostafazadeh, R. and Jalalpoor, S. (2017). Nationalization of the Oil Industry inIran and the Fadaiean of Islam, Journal of History Culture and Art Research, p.81-87.

Moin, B. (2005) Son Devrimci Ayetullah Humeyni, Ankara: Elips Kitabevi.

Nguyen, B. (2014). The Vietnam War Was the Price Too High for the United States of America?, (Unpublished Master's Thesis), Gent University, Faculty of Arts and Philosophy, Belgium.

Painter, D. S. and Leffler, M. P. (2005). Origins of the Cold War: An International History, Second Edition, Uk By Routledge.

Rahman, Z. A., Ghazali, A. S., Fauzı R., Yaacob N. H. (2013). Britain, The United Nations and the Iranian Crisis of 1946, Middle-East Journal of Scientific Research, Volume 18, Issue 11.

Ralph, J. (1999). Security Dilemmas and the end of the Cold War, Review of International Studies, British International Studies Association, Vol. 25, No. 4, Cambridge University Press, p.721-725.

Shawcross, W. (1991). Ahirin Sefer-İ Şah, Trans. Abdurrıza Huşeng Mehdevi, İntişarat-İ Elborz, Tahran.

Sönmezoglu F. (2009). Uluslararası ilişkilere Giriş, Der Yayıncılık, İstanbul.

Suh, J.J. (2006). Producing Security Dilemma out of Uncertainty: The North Korea Nuclear Crisis, Mario Einauidi Center for International Studies Working Paper Series, No. 8-06.

Uygur, H. (2016) 1953 Darbesi ve Hatırlattıkları, 2016, Access: Https://İramcenter.Org/1953-Darbesi-VeHatirlattiklari/\#.W3drztg5sls.

Üşür, S. (1991) Din Siyaset ve Kadın, İstanbul: Alan Yayıncılık, İstanbul.

Wendt, A. (2012) Uluslararası Siyasetin Sosyal Teorisi, İstanbul: Küre Yayınları.

Wendt, A. E. (2013). Anarşi Devletler Ne Anlıyorsa Odur: Güç Politikalarının

Sosyal İnşası, Uluslararası İlişkiler Konseyi Derneği, Uluslararası İlişkiler Dergisi, pp. 3-43.

Websitesi:

https://www.apnews.com/84d3401e09d6e88dac38c9cbe6f81ffb

https://www.nytimes.com/1970/06/29/archives/the-guam-doctrine-asian-nations-voice-anxiety.html https://iramcenter.org/1953-darbesi-ve-hatirlattiklari/\#.W3dRZtG5Sls

https://www.researchgate.net/publication/37146990_Rethinking_the_Security_Dilemma 